\title{
Making and Studying Notes
}

\section{Towards a Cognitive Ecology of Annotation}

\begin{abstract}
To paraphrase Edwin Hutchins, a "cognitive ecology" is a study of a cognitive phenomenon in its whole context - material, biological, anthropological, psychological, social, historical. Here I argue that annotation's cognitive ecology has potential for richly informing the application of digital techniques to making, studying and transforming all manner of annotative practices. The Cognitive Sciences have much to say that would be of help in reorientating our perspective to bring the dynamic variety and inventive genius of these practices into focus before we attempt implementation.
\end{abstract}

Keywords: Practice Theory, Commenting, Note-Making, Cognitive Ecology, Cognitive Sciences, Epistemology

\section{Thinking with hands and whatever comes to hand}

In his classic study Cognition in the Wild, Edwin Hutchins shows how much close ethnographic study can tell us about thinking with eyes and hands in the context of disciplined work with navigational equipment (1995; cf. 2010). He documents the cognitive systems they form together with the instruments and objects this work involves. "Humans create their cognitive powers", he argues, "by creating the environments in which they exercise those powers." ${ }^{1}$ Such cognitive systems "exist in all facets of our lives" but unfortunately studies of them are relatively rare $(1995,371)$. He lists 13. More have been done since he wrote, supported by the work of Anderson, Clark and many others. ${ }^{2}$ But in every area of disciplined activity there remains much to be done.

1 Hutchins (1995), xvi. Note that his ethnographic study is chiefly concerned with navigation on a large naval vessel, although he does discuss traditional Micronesian navigation knowledgeably at length (1995, 65-93), based on an earlier hands-on study. His emphasis in the book is in consequence on knowledge crafted into instrumentation rather than held in the sailor's head. There is much that the crew of a naval vessel does not have to know, hence the size, complexity and abilities of the ship are made possible.

2 See Anderson (2014), Clark (2008), Clark et al. (2013).

Willard McCarty, Prof. em., King's College London, www.mccarty.org.uk 
Studying the cognitive ecology of an activity we would implement is especially important lest we model its observable actions without taking into account the cognition which is done with and shaped by them. Here I consider annotation and attempt to sketch its cognitive ecology.

Annotation, like any subject worth the candle, grows larger, more various and complex the more you think about it. One reaction is to fall to definition as quickly as possible rather than seize the opportunity, not to get a grip on it but to see the extent of its embrace before you try to embrace it. At some point, if you want to have something useful to say, you must set limits for your subject, but having let annotation get out of hand, you can at least make an informed choice. Giving annotation free reign before deciding what you are going to say or do about it is important if you are a maker of tools and so must decide what the tool will afford the user of it and what it won't.

There is more to consider. Annotation is something people do in the world; making a tool for them, or just wanting to understand what they do, means taking the variety and variability of their practices and situations seriously into account. Among other things, it is an anthropological and cognitive psychological problem. I will come to the anthropology later. Now let me begin with a cognitive psychologist's words:

We think with our hands and our faces and our bodies. We think with the marks and the arrangements of marks we make on paper and the things and arrangements of things in the world. You might counter, but all that goes through the brain. Of course, nearly everything goes through the brain. Eating goes through the brain, from the biting and chewing onward. As does walking. Nevertheless, we don’t say we eat or walk with the brain. (Tversky 2014, 3-4)

\section{Marking the world}

In Marking the Mind, historian of psychology Kurt Danziger shows in detail the key role of metaphors in the conception of memory (2008, cf. Draaisma 2000). The most persistent and influential of these have been metaphors of inscription, dominant at least in part because, Danziger suggests, "The memory of homo sapiens appears always to have relied on some form of inscription on an external medium." $(2008,27)$ In the Western tradition, the usual starting point is Plato's analogy of the wax tablet on which memories are impressed like stamps (Thaetetus, 191c-d). Plato's tablet shares with other popular analogies a concrete, material basis, which gave it "a technological aspect... capable of enormous historical development in terms of the medium employed and the gradual exploitation of possibilities offered by these media" (Danziger 2008, 27). In addition to the wax tablet, we can cite, for 
example, the scroll or codex, the phonograph record and the photograph. Each in its time inflected the idea of memory differently. Now the digital computer is dominant.

The computer brought along with it the very difficult problem of how in various media to engineer the 'memory' John von Neumann had imagined in his architectural sketch ([1945] 1993). In time the goal of absolute accuracy (getting out exactly what was put in) was more or less achieved thanks to extravagantly engineered error-correction mechanisms that maintain the crisp binary signals and logic we mistakenly think are a given. It seems plausible that the much publicised accuracy of the machine had a role in strengthening the notion that remembering is to be judged by its objective faithfulness to what has 'actually happened'. Although that idea is still with us, the early twentieth-century psychologist Frederic Bartlett's prescient turn from memory to remembering, and the constructive "effort after meaning" he identified in remembering, set a different course, towards James Gibson's idea that cognition takes place by means of the variable affordances which the world provides. ${ }^{3}$

Hence annotating becomes a site not so much for recording or recalling, rather for knowing-in-doing. In other words, when marking the world with our thoughts (on scraps of paper, on a wall somewhere, with an app on a mobile phone etc.) we are thinking with whatever affordances come to hand. We couple ourselves temporarily with these affordances in a kinaesthetic-cognitive intercourse that binds together note-maker and physical medium in order to bring thoughts into being and communicate them. ${ }^{4}$

But let us temporarily put aside the 'thinking' and consider the 'whatever' with which this thinking is done. Consider that each 'whatever' affords some kinds of annotating and not others, and that once chosen it affects and shapes the thinking done with it. So the variety of the affordances matters. It matters to the annotator, to the student of annotation and to the systems designer.

I want to put strong emphasis on the form-changing fluidity and multiplicity of annotation's practices. I want to stay the implementer's hand from reaching prematurely for the XML spanner or the programmer's toolkit. I want to persuade the note-maker to consider simpler, older means before conforming his or her practice to available software. I want to delay the scholar from hiring a technical

3 (Bartlett [1932] 1995; Gibson [1979] 1986). See also e.g. Hutchins (1995); Clark (2008) and Anderson (2014). Daston and Galison (2007) is in this tradition.

4 On 'coupling' in cybernetics and biology, see Keller (2008, 71); Maturana Romesin (2002); Pickering (2010); more generally, see Neumann and Cowley (2017); Etzelmüller and Tewes (2016), esp. the chapters by Tewes and by Gallagher and Ransom. The literature on conversation is also very helpful; see Taylor (2016), esp. Chapter 2. 
expert to encode his or her sources without first interrogating the gulf between them and what is to be known from them.

Let us consider first the maker, then the reader of notes.

\section{Note-making}

Nowadays the note-maker, wanting the benefits of the machine, looks for a fit app, perhaps finds one and gets to work. Almost inevitably, however, he or she runs into the app's limitations. Seeing an opportunity, but before reaching for the toolbox, the properly educated systems designer will consider what's been done and what's available, then talk to many note-makers about their practices, likes and dislikes. Experience suggests to me - I've actually done this - that such anthropological fieldwork and time spent with the relevant literature will not converge on a single, one-size-fits-all design, and that the elusiveness of such a design is fundamentally not due to the shortcomings of current technologies. The basic problem is that notemaking is not itself singular nor does it tend to settle down for good. Indeed, it is not an 'it' but, as I suggested, a fluid mode of thinking-by-doing realised in a coupling with one or more of the world's affordances, taken up then abandoned as suits the occasion. Note-making is not invariant across research projects, the individuals who pursue them, their subject areas and the physical media and circumstances involved. It may vary, possibly for no identifiable reason, even from one day to the next. The point is not at all that the means are irrelevant - they are indeed essential in their concrete particulars - rather that couplings are impermanent, answerable to the variable situation of note-making.

Now I want to get personal and specific, to talk about my own note-making practices in an ongoing project. The technologically minimalist style I am about to describe is not how I always take and use notes, but I have often worked in this way when the project is large in scope and complex. Again, experience has taught me that no one size or even a discrete range of sizes will fit all circumstances or even a majority. We must begin with specific examples, of which this is one. But my point is to exemplify the coupling, not promote a particular method or tool.

Index cards and the boxes they were kept in were universal to research when I began my doctoral dissertation, but I only realised the full potential of index cards when I encountered the great James Murray's lexicographical method. In his "President's Address" to the London Philological Society (Murray 1884), he described how he composed entries for the Oxford English Dictionary by arranging and rearranging the slips of paper which recorded actual uses of words that had 
been contributed by his large network of readers. The lexicographer, he wrote, takes the slips pertaining to a particular word and

spreads them out on a table or on the floor, where he can obtain a general survey of the whole, and spends hour after hour in shifting them about like pieces on a chess board, striving to find in the fragmentary evidence of an incomplete historical record, such a sequence of meanings as may form a logical chain of development.... Such is the nature of the task; those who think that such work can be hurried, or that anything can accelerate it, except more brain power brought to bear on it, had better try. $(1884,510)$

Markus Krajewski comments in Paper Machines that despite the undeniably transformative effects of digital technologies, things also "remain the same": the cardindex continues to surface, as it does with me, again and again. As I will demonstrate, it is undoubtedly laborious but when used well it is nevertheless marvellously efficient ([2002] 2011, 143). Krajewski cites Niklas Luhmann's account of his card index system, "the furnace in which the texts are forged". In an interview, Luhmann describes how his ideas come from a card-box of notes, by sorting and combining them.

The new ideas then arise from the different combinations of the notes to the individual terms. Without the notes, so by reflection alone, I would not come to such ideas. Of course my head is required to write down the ideas, but it cannot be held responsible for them alone. In that sense, I work like a computer, which can also be creative in the sense that by combining input data, it produces new results that were not predictable. ${ }^{5}$

The card-index is "like a computer" because both are fundamentally combinatorial (cf. Berge [1968] 1971), hence creative not only within but also by means of their constraints. Thus mathematician Martin Gardner: "When ideas are combined in all possible ways, the new combinations start the mind thinking along novel channels and one is led to discover fresh truths and arguments." $(1958,17)$ The question to ask of both digital and paper machines is where and how their artificial intelligence arises: in the coupling with the enquirer, yes, but what happens there? Currently we do not have an answer, but we can start by not underestimating the power of knowing-by-doing and so pay attention to what changes when the observable actions of note-making are translated into software. What happens, for example,

5 "Die neuen Ideen ergeben sich dann aus den verschiedenen Kombinationsmöglichkeiten der Zettel zu den einzelnen Begriffen. Ohne die Zettel, also allein durch Nachdenken, würde ich auf solche Ideen nicht kommen. Natürlich ist mein Kopf erforderlich, um die Einfälle zu notieren, aber er kann nicht allein dafür verantwortlich gemacht werden. Insofern arbeite ich wie ein Computer, der ja auch in dem Sinne kreativ sein kann, daß er durch die Kombination eingegebener Daten neue Ergebnisse produziert, die so nicht voraussehbar waren.” (1987, 144 f., my transl.) 


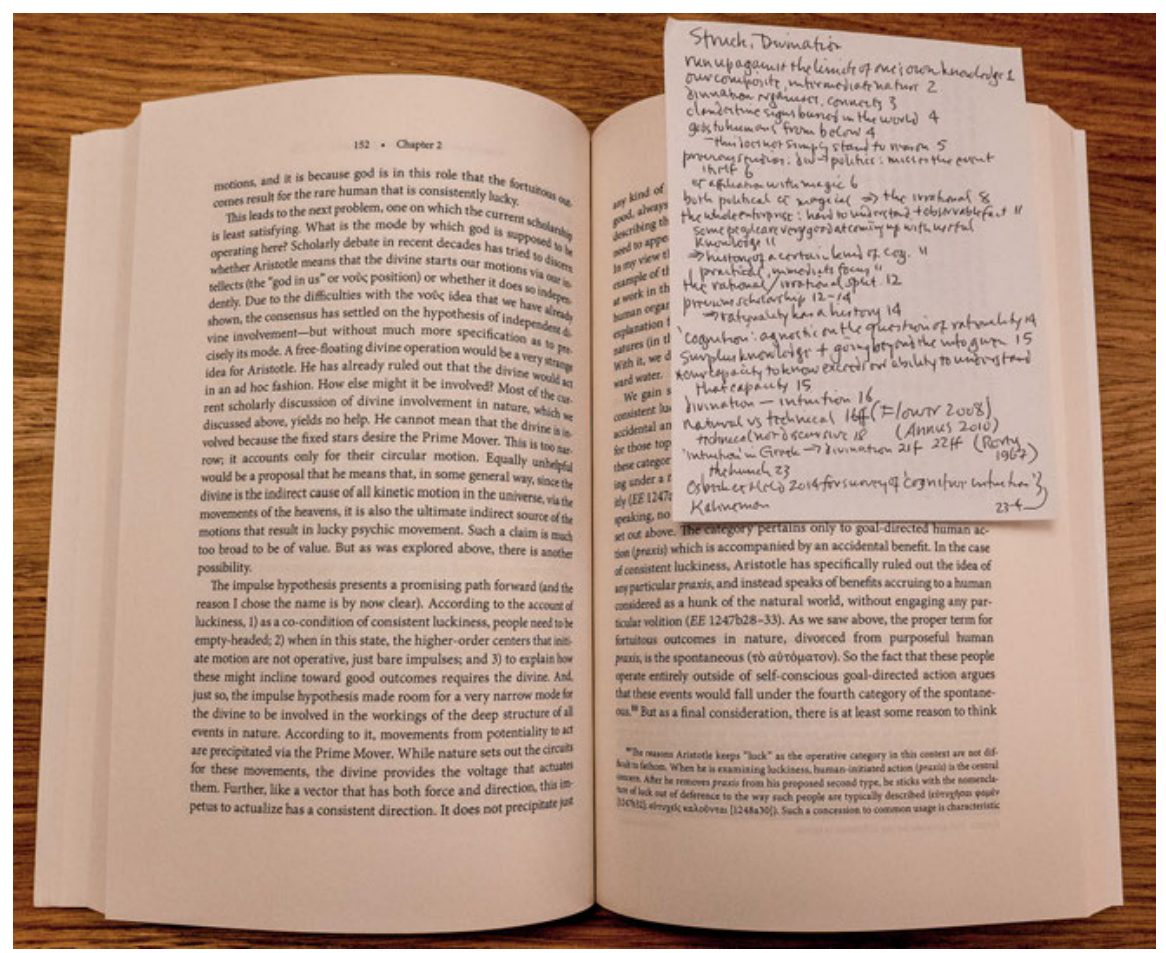

Fig. 1: Taking preliminary notes while reading a book

when the inchoate, shifting relationships expressed spatially by a desk strewn with piles of cards is rendered by screen-icons with named links between them? Much more needs to be known about the space between brain and card, mind and the worldly affordances to mindfulness. The examples I am about to give should help. But note: once again, there is nothing canonical here. I provide only an example. Again, what matters is that we pay attention at a fine-grained level to individuals' actions and experiences on particular occasions for particular projects. These are mine, illustrated here:

1. Very brief notes are taken on paper slips while reading a book. The idea here is to record ideas, keywords and references to other sources I want to come back to later for more detailed note-making. The highly variable circumstances under which reading can be done and the sheer convenience of taking notes in this way while reading a codex make it a very effective procedure. (see Fig. 1)

2. Alternatively, notes are taken from a digitised source, such as an article or book-chapter, displayed on screen. Notes are written, often with the aid of 


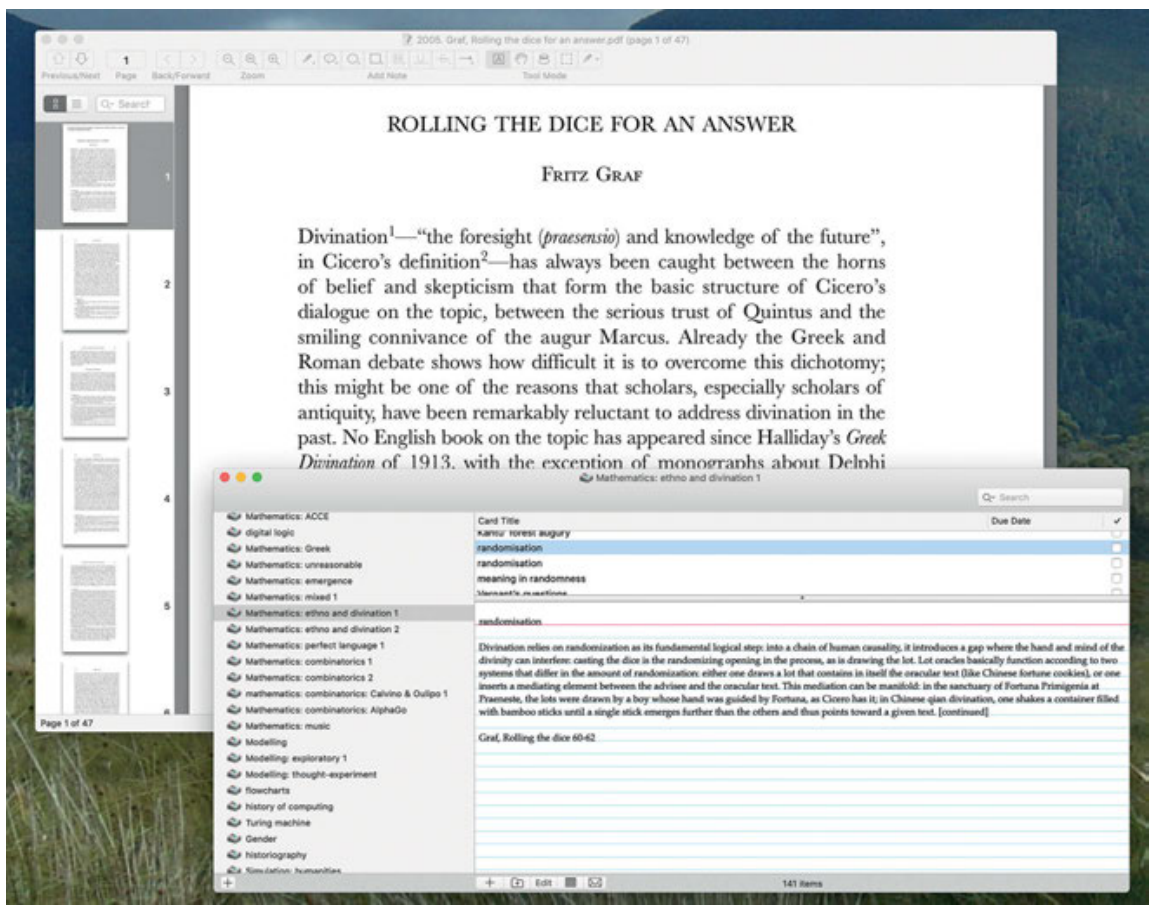

Fig. 2: Expanding and recording preliminary notes

cut-and-paste from the source, directly into a program (such as QwikCards, shown here). (see Fig. 2)

3. The very brief notes made at (1), above, are expanded, written into QwikCards from the book, which if at all possible has been digitized and is accessed on screen.

4. A topical collection of notes in QwikCards is printed, four to a sheet of paper, then cut into individual cards and stacked for sorting. The stack of printed cards is sorted into topical piles, labelled and clipped together. Cards may be resorted a number of times during this stage. (see Fig. 3 on the following page)

5. Notes are then taken with pen-and-paper from each of the labelled piles to attempt a proto-narrative. In simple cases, the resulting sheets are then used as prompts for writing; in more complicated cases, the individual notes on the sheets are cut up, pasted onto new sheets, scanned and printed before writing begins. (see Fig. 4 on page 279)

The labour and time involved should be painfully obvious. But note: equally important to the product - many pages such as the one in Figure 4 on page 279 - is 


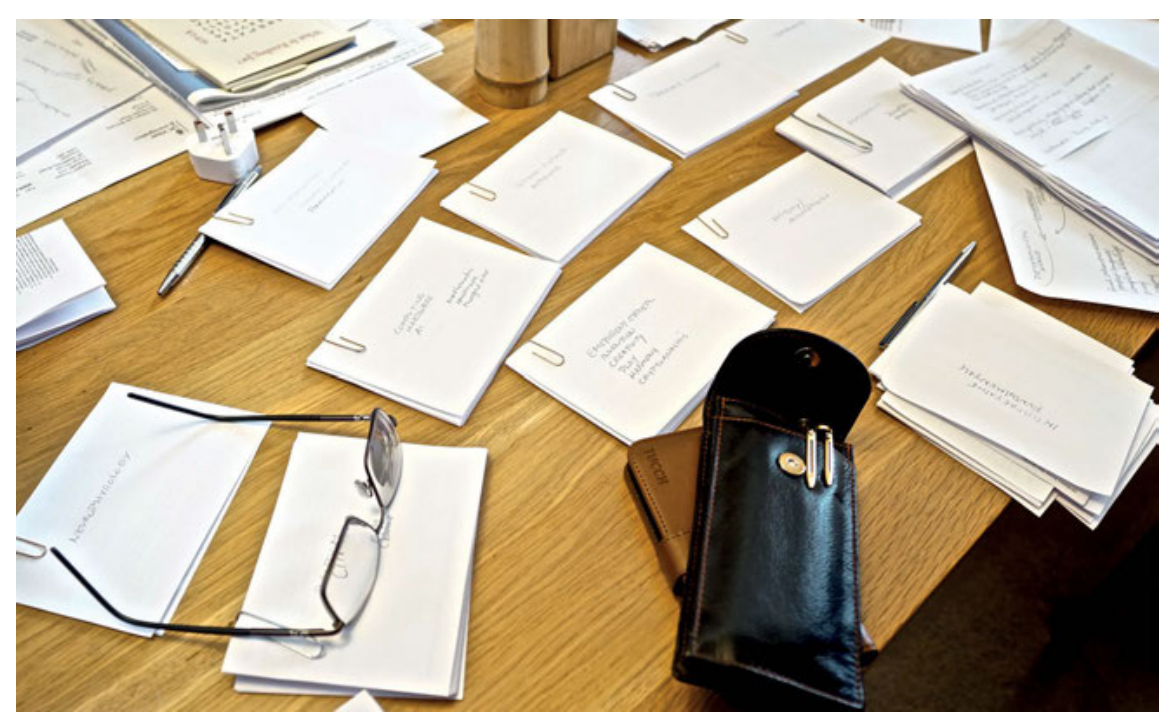

Fig. 3: Expanded notes, printed out and sorted topically

what is not and cannot be shown: the intellectual-kinaesthetic work of sorting out a highly complex subject and producing that proto-narrative. In my experience such labour and the invisible intellectual work are inseparable. The fact that the implicit links between cards and piles of cards are left implicit - changeable if not fluid, if not tacit, intertwined with inchoate feelings that an idea or cluster of ideas 'belongs with' or 'is far away from' or 'is quite unlike' another, or is a right-handed or left-handed sort of thing - is in my view essential.

Again, I am not saying that I always do things this way. In fact the cutting-up and reassembling of handwritten notes is something I've never done before in all the many years I've been note-making. It is new with this especially complex project. Again, I make up the process as I go along, more or less as seems to fit the occasion.

Before moving on, let me give recognition to the two most thoughtful software environments I know: NoteCards, devised at Xerox PARC in the 1970s, and Pliny, designed and built by my colleague John Bradley early this century. ${ }^{6}$ Neither of these made it to market; both were brilliant experiments conducted in the medium

6 On NoteCards see Halasz et al. (2001); Brown (1985) and Halasz, Moran and Trigg (1987); cf. Norman and Draper (1986), Chapters 11, 22 and passim; on Pliny, Bradley (2008, cf. 2012); for a survey of annotation systems, Hunter (2009). See also DeRose (1989). For Vannevar Bush's Memex, grandfather of all, see Nyce and Kahn (1991) and Engelbart (1962, 48 ff). 


\section{MATLAEMATICS \\ Phenomenological-Historical}

HANDS \& BRAIN

Dragramming in Gk.maths., Notz, shapin 61

closeners to the banausic'.

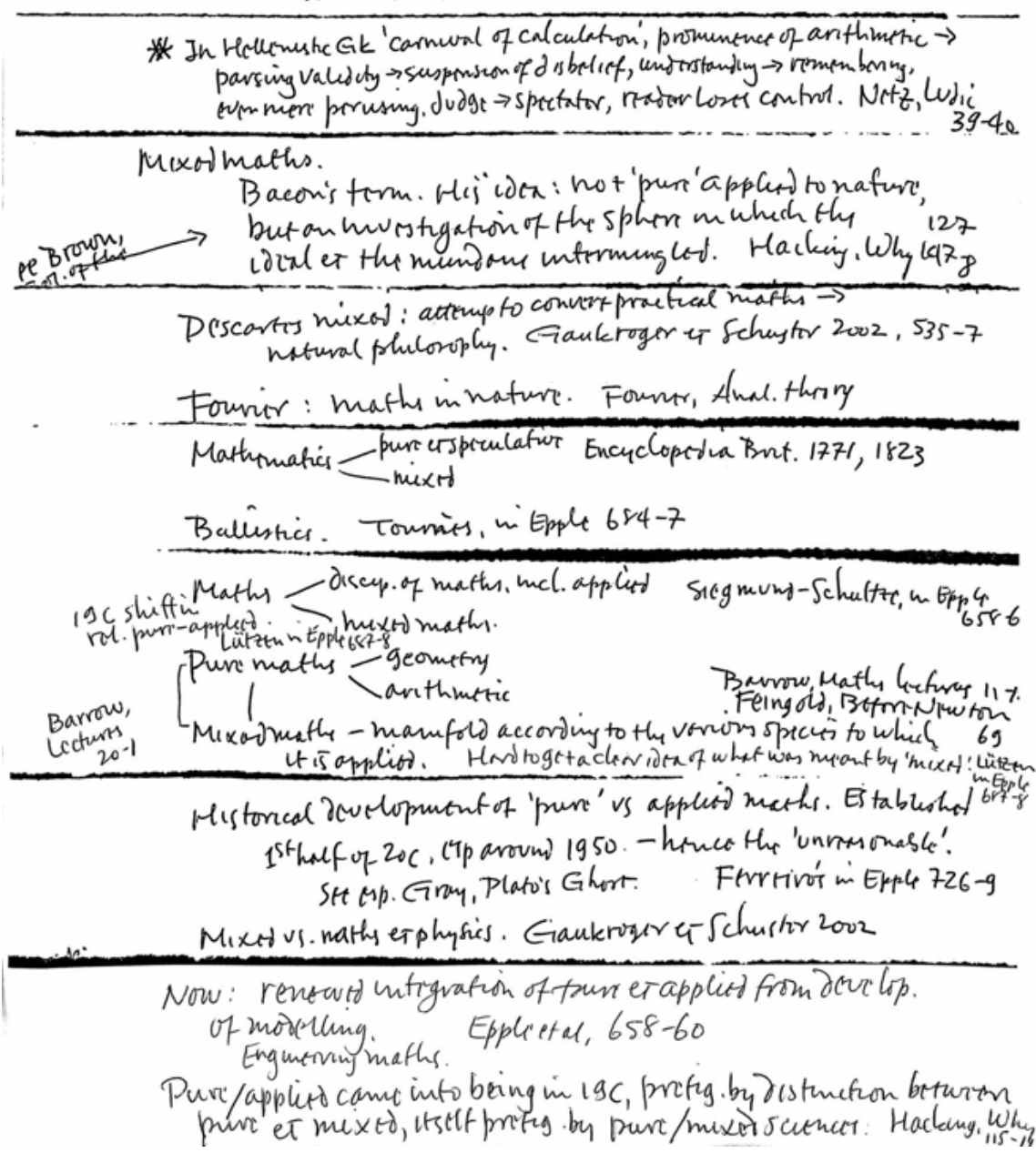

Fig. 4: Construction of a proto-narrative from a topical collection 
of software. I am not holding my breath for a system as good as these but better for my purposes than the methodological rag-bag I have just described. But the aim of designing and building such software is clear: better to understand the recursive mind-to-affordance coupling of note-maker to whatever medium.

\section{Reading annotations}

I turn now from the devising to the unpacking of notes, and so from the coupling of note-maker and material affordance to the probing of the trace that note-making makes and of its implicit coupling, intellectually, socio-culturally and historically.

Annotation is defined by the fact that it is secondary to something else, to a prior or original text, image, object or event. In the recent past, from the early to mid-nineteenth century until the last quarter of the twentieth, it was largely regarded by mainstream scholarship, if at all, as marginal in every sense. ${ }^{7}$ But within the last three to four decades it has become a topic of keen interest across the board as a part of a greater shift of attention from central to peripheral phenomena, or rather, to the decentring realisation of many perspectives. ${ }^{8}$

In the following I will focus on three examples of coupling in the study of annotations: a single complex gloss to a Late Antique text in an early medieval manuscript; a cognitive-historical study of nineteenth-century experimental science; and a contemporary graffito. These three unlikely bedfellows in combination with the account of my own note-making practices will provide a basis for some thoughts on the challenges that annotation poses to our understanding as well as to our plans toward realising better tools, including a 'digital edition' worthy of the name.

\footnotetext{
7 Jackson (2001), chapter 2, provides a very brief history from Greek scholia onward; the book as a whole is focused on annotation in England from the eighteenth through the twentieth centuries. For the Romantic period in English literature, see Jackson (2005); for medieval glossing, O'Sullivan (2018); Teeuwen and Van Renswoude (2017); Dinkova-Bruun and Major (2017), esp. the Introduction and O'Sullivan's chapter; Mayr-Harting (2008); Wieland et al. (2006), esp. chapters by Miles, Ruff, Wright and Dinkova-Bruun; Wieland (1983). For annotation from the perspective of implementation see Marshall (2010).

8 Eco ([1962] 1997, 1-14) “Introduzione” and (1989), with the Introduction by David Robey; Derrida ([1966] 2001); ([1967] 1997), together with the translator's Preface; Deleuze ([1968] 1994), chapters 1 and 6; cf. Donato (1973); Inwood and McCarty (2010).
} 


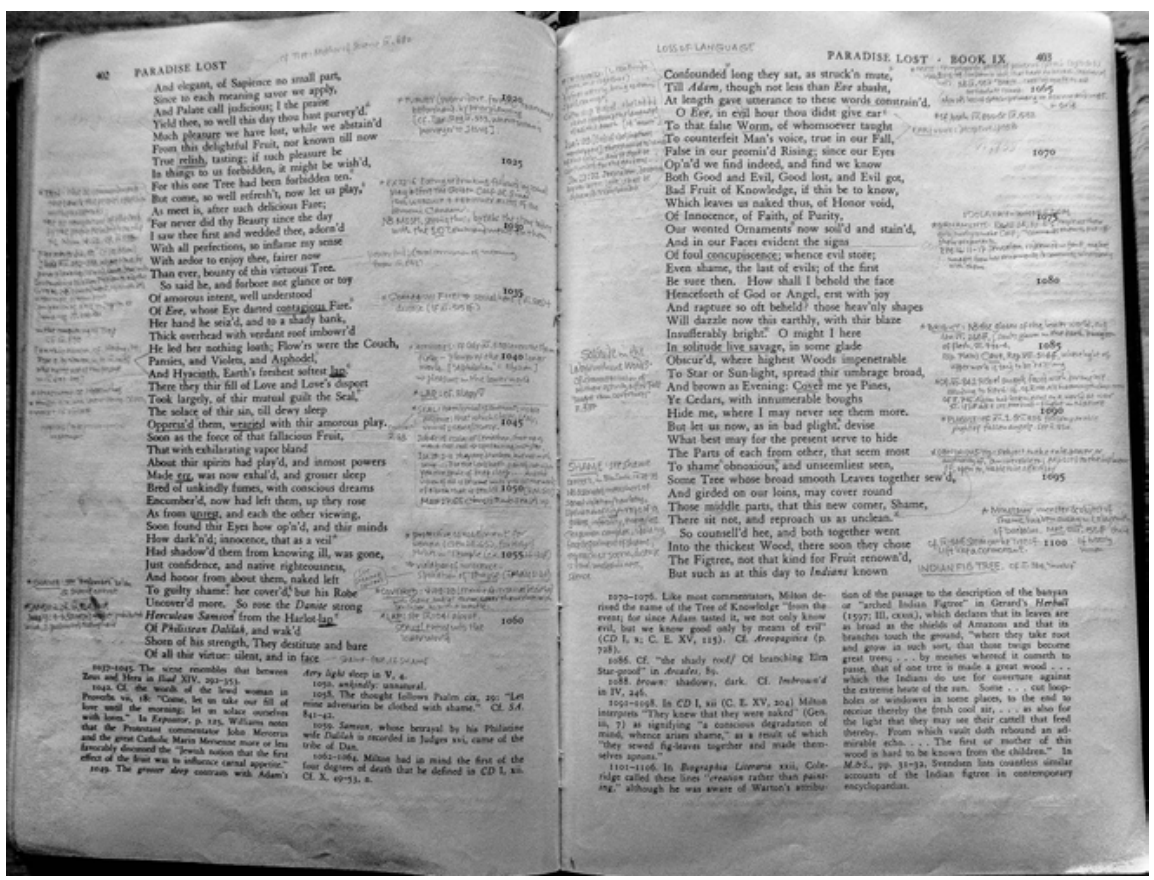

Fig. 5: A student's marginalia

\subsection{Glossing as a discipline}

Although writing in books is for us often an anathema, scholars still make marginal annotations when focused on a single text, as in Figure 5 - an opening from my copy of John Milton's Paradise Lost, which I annotated during my doctoral research.

In medieval manuscripts such 'glosses' were likewise written in the margins and between the lines of a text. Figure 6 on the next page shows a page from such a manuscript: page 10 verso of Leiden BPL 36, a ninth-century manuscript of Martianus Capella's early fifth-century work De nuptiis Philologiae et Mercurii ("On the marriage of Philology and Mercury"). ${ }^{9}$ De nuptiis is an intricate allegorical exposition of the seven liberal arts - grammar, rhetoric, and logic (known as the trivium) and geometry, arithmetic, music, and astronomy (the quadrivium); these formed the basis for medieval education, to which we remain indebted. Keep in mind that when the glossator set to work, De nuptiis was a 400 year-old text written

9 I am indebted to Sineád O’Sullivan for the example, pointers to scholarship and comments on this section of the paper. Thanks to André Bouwman, Leiden University Library, for permission to reproduce Leiden BPL 36, $10 \mathrm{v}$. 


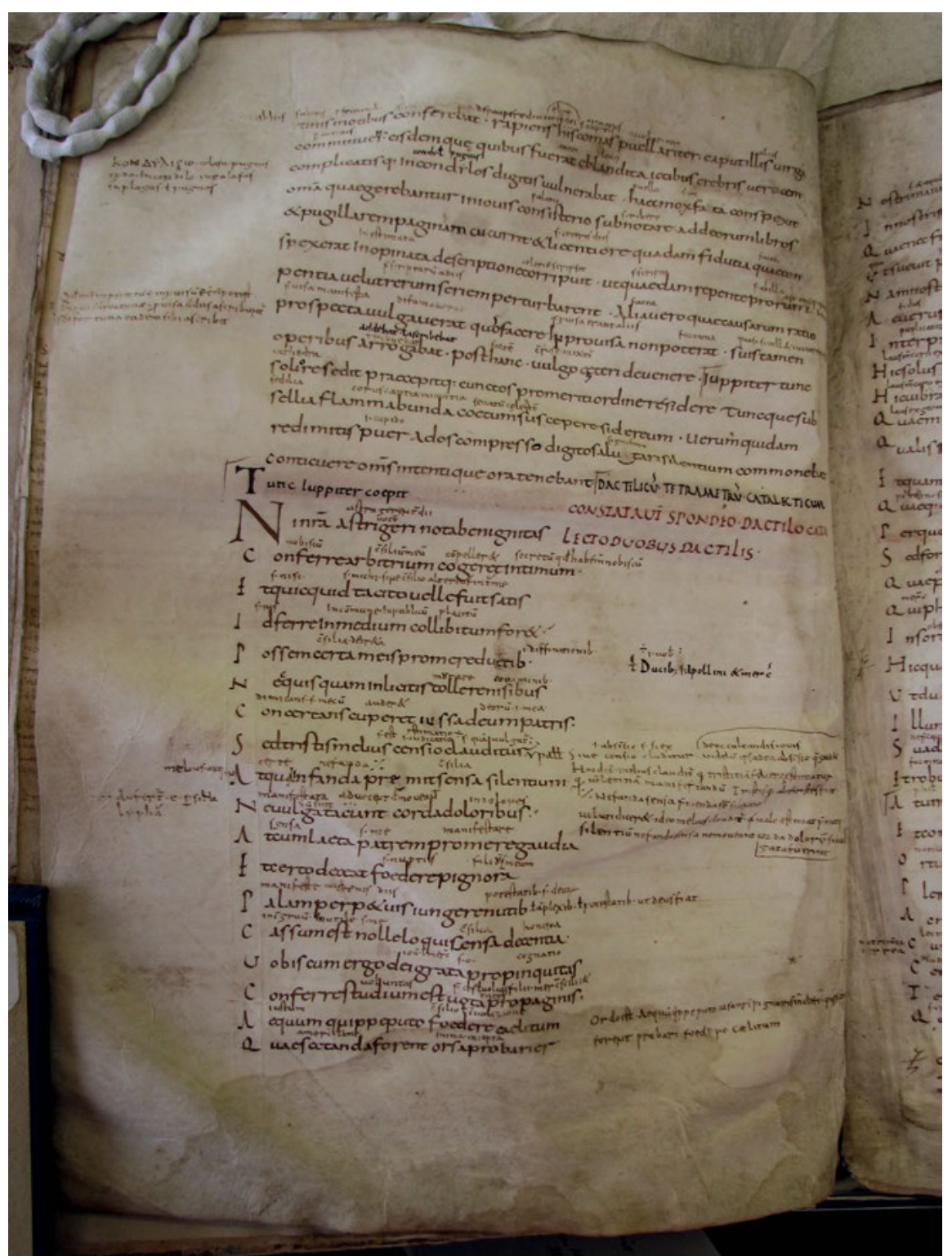

Fig. 6: An annotated ninth-century manuscript (Leiden BPL 36, 10v) 
under very different cultural, intellectual and linguistic conditions; it was being put to use for very different ends. Such books were costly to produce. ${ }^{10}$ Glossing was a serious matter.

Often, but not always, marginalia of the kind shown here were written by the same scribe who wrote out the text on which he or she then commented. ${ }^{11}$ They can be primarily lexical, grammatical, syntactical or hermeneutical; they are often intertextual, sometimes citing authorities by name, sometimes only echoing them. Functionally, that is, glosses have two main purposes. The first is to clarify the literal meaning of the text on which they comment (Wieland 1983); the second is to interpret, or rather, to engage if not entangle the reader in an interpretative struggle. Sinéad O'Sullivan, for example, argues that medieval readers must on occasion have had great difficulties understanding the glossator's obscurities and responding to the intertextual demands, and that we have good reason to suppose that these difficulties were created deliberately (2012). We can in any case note the difficulty that medieval readers, however scholarly, must have encountered in order to make sense of hermeneutical glosses.

Modern readers may well bridle. In the Anglophone orbit, readers have been schooled for centuries in the policy vigorously advocated in the seventeenth century by Thomas Sprat, to practice "a close, naked, natural way of speaking" and writing, stripped of figurative language, "bringing all things as near the Mathematical plainness" as possible (1667, 113; cf. Frazer 1960). In other words, moderns in my tradition, apart from all the usual challenges of an historical source, must work even harder than the medieval reader, who would at least have expected "a kind of reading that was by nature slow, complex, open-ended, non-linear, fragmentary, multivalent, and requiring effort... driven not by the provision of a single interpretation but one that embraced variety and multiple possibilities." (O'Sullivan 2017, 372, 382) (Imaginative language, especially poetry, has always involved this kind of reading, of course.) Medieval readers would have expected glosses, unlike the modern footnote in an authoritative scholarly edition, to refer to all manner of intertextual sources. Moderns must take great pains not only to recreate imaginatively what the medieval reader knew and expected and to engage in the same struggle but also to enter the fray knowing that the glossator's

10 Reynolds and Wilson, citing the recorded cost of books in the library of Arethas of Caesarea (early 10C), note that his Euclid cost 14 gold pieces, his Plato 21 pieces, whereas "civil service salaries started at 72 gold pieces per annum, and might rise in exceptional circumstances to 3,500. Book collecting”, they conclude, "was not a hobby for men of modest means.” $(1991,64)$ 11 Mayr-Harting (2011, 53 ff.) cites abundant evidence of learned women scribes and glossators at Chelles, Seine-et-Marne, Paris, in the Carolingian period. 


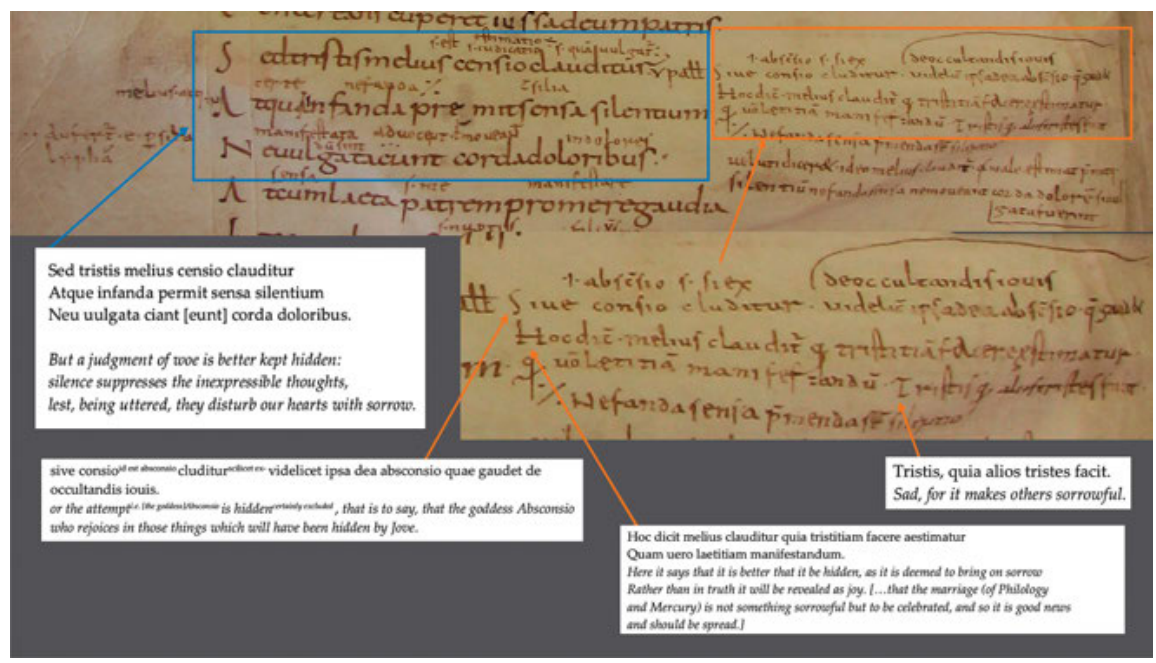

Fig. 7: Enlargement of 3 glossed lines from Leiden BPL 36, 10v, with transcription and translation

precise intention in the hermeneutical cases was to conceal in order to reveal. ${ }^{12}$ However we profess not 'to think like a computer', we are schooled by it, as well as by Sprat's legacy, to make explicit and to simplify to a "Mathematical plainness". The manuscript evidence goes directly against this schooling, attesting to a high probability that the effect if not the glossator's intention was to ensure as much as possible that the reader would struggle, per aspera ad astra, for an understanding of the profound matters that the text addressed.

My first example provides just such evidence. Figure 7 enlarges the three lines and the glosses from Leiden BPL 36 that I want to discuss. Translations and expansions of the common Latin abbreviations are provided.

The medieval reader would have had no trouble with Martianus' text: the pages of the manuscript are elegantly laid out, the handwriting is clear and the Latin untroubled. With this manuscript and with glossed manuscripts in general, however, difficulties begin with the glosses, which complicate the layout and make "the mise en page of early medieval glossed manuscripts... far from straightforward" (O’Sullivan 2017, 384), as follows. "The reader not only has to correlate the various glosses with their corresponding lemmata, but also has to disentangle and reassemble information." (O’Sullivan 2017, 388) For the three glosses shown (sive

12 See the discussion of the integumentum in Dronke (1974); cf. Dronke (1992), esp. Chapters 1 and 2 . 
consio cluditur...; hoc dicit melius...; tristis, quia alios...) the steps are something like this:

(1) make the link between the first gloss and the lemma in the main text (censio clauditur);

(2) for the first gloss, figure out how to integrate its secondary gloss (id est absconsio, whose lemma is consio in the primary gloss; then scilicet ex-, for which cluditur is the lemma);

(3) read absconsio as a plain noun (which doesn't make much sense), or somehow know that it is the name of a goddess, or leave the reading of absconsio in suspension and proceed to the remainder of the sentence, piece it together with its superscripted run-on, then return to id est absconsio to resolve the problem;

(4) by reading the second gloss and the text, make the link between Hoc dicit... and the lemma melius...clauditur;

(5) figure out that Tristis... is a separate gloss and connect it with its lemma tristis.

In sum, unravelling and piecing together makes the reading difficult: "information... is not immediately accessible on account of (a) the layout of the glosses (e.g. with one of the marginal glosses written over two lines) and (b) layering of annotation (e.g. glosses on glosses).” (O’Sullivan 2017, 390)

Again, the task delineated here is not to produce such a step-wise recipe as I have given, which in any case is very far indeed from a complete and faithful account of all that was or could have been involved in a typical reading of the manuscript. Rather it is better to appreciate the coupling intended, and what it was designed to accomplish (cf. O’Sullivan 2012).

\subsection{Experimental science}

To be clear: 'coupling', thus far, is still mostly a promissory note for a dynamic, reciprocal relationship that, I am arguing, is common across practices of annotation. My examples, of which the following one is the most analytically satisfying, will help me make good on the promise. But for now I would ask you kindly to be patient.

The link that makes experimental science kin to the glossator's work begins with Thomas Kuhn's historicisation of science in The Structure of Scientific Revolutions in 1962 and with Ian Hacking's philosophical demonstration of the inde- 
pendence and creative role of experiment in 1983. ${ }^{13}$ Until Hacking's intervention, followed by the work of Peter Galison and a number of others, experiment was largely regarded as mere servant to theory, not much more than a way of testing theories for their robustness. At about the same time as Hacking's declaration that "Experimentation has a life of its own" $(1983,150)$, historians began turning to scientists' laboratory notebooks to study the life of experiments, "to seize them as much as possible with [the experimenter's] discovering hands". ${ }^{14}$ The result has been studies of two kinds, one primarily historical, the other 'cognitive-historical', combining Cognitive Psychology with History in order to bring the historical processes of thought, insofar as they can be known, to light.

Here I refer primarily to one of these cognitive-historical studies: David Gooding's Experiment and the Making of Meaning, ${ }^{15}$ which draws on nineteenth-century natural philosopher Michael Faraday's meticulously detailed Diary, comprising handwritten notes and diagrams detailing the progress of his experiments (Faraday 1932-1933; cf. Gooding and James 1985).

Gooding distinguishes three phases of exploratory enquiry in the natural sciences, of which only the first is directly relevant here: the interactive manipulation of phenomena. ${ }^{16}$ Hans-Jörg Rheinberger usefully describes it as combinatorial play: "an exploratory movement, a game in which one plays with possible positions, an open arrangement... a game of combinations still unrestricted by the rigorous limits of stringent compatibility" with established findings ([2006] 2010, 246-247; cf. Steinle [2005] 2016, 1-3) The crucial matter is the experimenter's agency in play against the ambiguity and uncertainty inherent to exploration of the coupling in which the enquirer and the subject of enquiry meet.

Gooding's keyword for this shifting, dynamic coupling and its product is 'construal': ${ }^{17}$ more action than thing but sometimes both, a phenomenon in the active

13 Note Hacking’s “Introductory Essay” (Kuhn [1962] 2012, vii-xxxvii); and his "Introduction, Rationality” (Hacking 1983, 1-17).

14 Buchwald (1994, 329). For the study of exploratory experiments overall, see Steinle ([2005] 2016); Tweney (2013); Nersessian (2008). Examples of case studies are of Antoine Lavoisier (Holmes 1985), Michael Faraday (Gooding 1990), Heinrich Hertz (Buchwald 1994) and James Clerk Maxwell (Nersessian 2002).

15 Gooding (1990). For an assessment and update to Gooding's work see Steinle ([2005] 2016), esp. Chapter 7.

16 The natural sciences diverge from the human sciences in the remaining two phases, isolation of phenomena from the instruments and actions which produce them, and the shift from "a private world of percepts and objects to... a public world of talk about objects.” (Gooding 1986, 209; cf. Jacob [1987] 1988, 296 f.; Keller 1996)

17 See esp. Gooding (1986 passim; 1990, xv-xvi, 23, 25-27, 74, 82, 85-88, 115-116, 124-128, 142, 271; 1992, 102-104). Cf. Tweney (2013). 
sense of phenomena an experimenter brings to light or makes appear (phaínei). Construing is a step-by-step feeling of a pathway, prior to interpretation, towards a communicable form of experience it both creates and integrates "into an existing system of experimental and linguistic practices understood by others." (Gooding 1990, 80) A construal "cannot be grasped independently of the exploratory behaviour that produces it or the ostensive practices whereby an observer tries to convey it." (87) If construing is successful against further exploratory work, it “creates 'givenness' in experience”. (87) Faraday, Gooding writes, “wanted his audiences in the great lecture theatre of the Royal Institution to think of themselves as being in 'Nature's school'." (1985, 105-106) But Faraday was headmaster.

In the natural sciences, that is, givenness is secured by the ubiquitous but problematic concept of 'nature'. ${ }^{18}$ The more fundamentally interpretative disciplines of the human sciences and the arts have no such backstop, but they share the site of epistemic formation Gooding calls 'construal'. The American literary scholar Elaine Scarry has suggested that all cultural productions share the creative phase of the "made-up"; the natural sciences alone go on to the subsequent phase of the "made-real" (1992). Gooding similarly remarks that the creative practices of artists and experimenters are "not so different in aim or processes". ${ }^{19}$ But the new is more than novel. Somehow, he comments, the new - we do not know how - "retains enough of its anomalous character to promote changes in a... system that has apparently assimilated it.” $(1990,29)$ The new serves as a channel for the profoundly disruptive: "The new is shocking”, Vilém Flusser writes, "not because it is one thing and not another, but because it is new." ${ }^{20}$ Ordinary note-making seldom merits such strong language, but some medieval annotations and some scientific notebooks certainly do.

But, having sighted, followed and made inferences from the spoor provided by Faraday's notes, Gooding declares that “Construing involves a complex array of actions in material and mental space which I shall not attempt to reconstruct. Construals mark the limits of my interpretation." ${ }^{21}$ James Clerk Maxwell likewise declared he would proceed no further, as he wrote, toward the "still more hidden and dimmer region where Thought weds Fact". "Does not the way to it pass through the very den of the metaphysician," he asked, "strewed with the remains of former explorers, and abhorred by every man of science?” ([1870] 1890, 216) Perhaps we can get no further. But Maxwell had a strategy for advancing research amidst the

18 Williams ([1976] 1983, 219-224); Lloyd (1991), (2012, 58-59 and 2018); Rochberg (2016).

19 Gooding (2003, 262); cf. McLeish (2019).

20 "Das Neue ist entsetzlich. Nicht, weil es so ist und nicht anders, sondern weil es neu ist." (Flusser 1997, 125, my trans.)

21 Gooding (1990, 142); cf. Holmes (2004, 96-98) and Chapter 10. 
difficulties of great challenges (which serious note-makers also face). His strategy was to lay hold of a clear, empirically well-grounded conception from an analogous field, "without being committed to any theory founded on the physical science from which that conception is borrowed". ${ }^{22}$ Insistence on "the necessity of systematic doubt, of complete mental freedom when confronted by generally held theories", as Claude Bernard insisted, does not imply ignorance but detachment (Taton 1957, 44; Bernard 1949, 35-43).

Maxwell's requirement, that is, was for a kind of aporia. It was a requirement for the ability most economically described by the poet John Keats in a letter to his brothers, when "at once it struck me, what quality went to form a Man of Achievement ... - I mean Negative Capability, that is when man is capable of being in uncertainties, Mysteries, doubts, without any irritable reaching after fact \& reason". 23

\subsection{A graffito}

Both preceding examples pose intricate, labyrinthine pathways to be threaded: the first (a medieval gloss) devised by a learned scribe to entangle his or her learned readers in a spiritual quest; the second (notes on the emergent phenomena of electromagnetism) posed by the physical world but crafted by a skilled scientist during an exploratory experiment, then communicated to colleagues and the public. My third example - a contemporary graffito - is in many respects utterly unlike the first two, but I want to make some progress toward picking out the common ground. ${ }^{24}$

The term 'graffiti', the editors of Scribbling through the Ages note, "was originally a scholarly term coined by the classical archaeologists who excavated Pompeii in the nineteenth century to describe an ancient and specialized form of inscription.... The contextually restricted, highly academic origin of the word - as well

22 Maxwell (1864, 27-28); cf Gooding (1990, 88). I read 'theory' in this context to refer to a formal statement, usually in mathematical form, not the sort of assumptions or ideas about the world one may have, many of them tacit and inchoate; see Gooding (1986, 222); Hacking (1983, 173).

23 Keats, letter to George and Tom Keats, 21 December 1817, in Keats (2002, 60); cf. Ou (2009); Bate ([1939] 2012). The connection with scientific creativity was made by Crawford (1985, 218-220) and Ippolito and Tweney $(1995,441)$.

24 Much can be learned from discussions of ancient examples; see e.g. the following note and Lewisohn (2009, $26 \mathrm{f}$.). Studies of contemporary graffiti emphasise non-verbal 'street art' rather than verbal graffiti; see Lewisohn (2009, 30-35) for the development from 'tagging' of names to non-verbal art, also Mailer (1974) on tag and name; for cultural analysis, Neef (2007); for the gestural component, Flusser ([1991] 2014). 


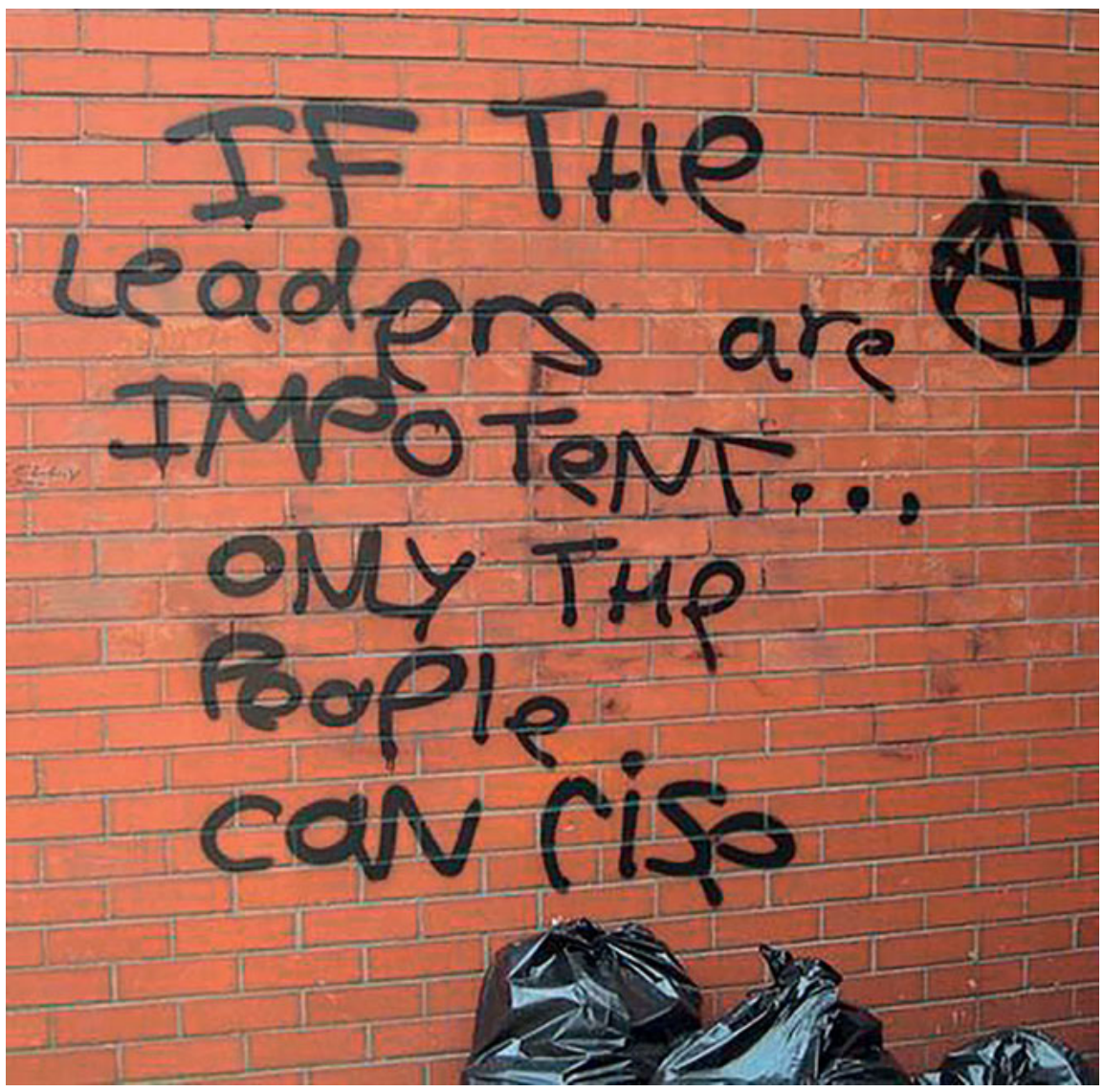

Fig. 8: A Belfast graffito

as the realia that go with it - have largely been absorbed into modern street culture...." ${ }^{25}$ In her consideration of medieval glossing Janine Rogers begins by looking in the opposite direction, from modern use of the term back to its recognition "as a reality of medieval manuscripts" $(2018,175)$. But which of the many realia are in common across the many forms? When planning an implementation of the arts of note-making and taking the scholarship of annotation into account, the systems designer must of course choose but should have in sight the largest possible field of those commonalities.

25 Ragazzoli, Harmanşah, Salvador and Frood (2018, 1-2 [my emphasis]); cf. Baird and Taylor (2010). 
My contemporary graffito is shown in Figure 8 on the previous page, a photograph I took of a spray-painted remark on a brick wall in Belfast, Northern Ireland, in ca. 2010, two years after the financial crash. By then the Troubles were long over, though not the seldom-reported sectarian tensions one can find evidence of to this day. There are no explicit intricacies in this example, but much is implicit. Surely we can detect a sexually tinged insult and threat here to 'impotent' British and Northern Irish politicians from an unspecified people threatening to 'rise', with implications within living memory as well as the murals and flags. After the first line, however, the words droop, not rise; if you know Belfast, particularly places like Edinburgh Street, it is hard to deny that the drooping is meaningful. The writer might have been bending over, and so inclined to write in a downward slope, but the result communicates anything but rebellious power. Were rubbish-bags there when he or she spray-painted the words?

A whole world and a history, then, are contained in that graffito, confirmed on the streets of the city if you know how to look. To me south Belfast is a pleasant enough place to live. But I look with different eyes than the author of this graffito until I read it and so get an empathic troubling glimpse of his or her world.

If, as I think is the case, all is in the long moment of the writing of this graffito, then here too we have a coupling.

\section{The challenges of implementation}

I have argued that note-making is best served by a miscellany of relatively primitive tools that can be freely picked up and combined to suit the occasion, and that the index card (on paper and on screen) is likely to be one of them. How the variable process of writing, sorting and reassembling of index cards does what it evidently does seems in part to lie in the "den of the metaphysician", but it is clear that the cards' recombinatorial potential plays a large and important role. Can software do any better? I am not sure, even after trying out NoteCards and living with Pliny. I do not think we can make any assumptions about "the future of reading” (Marshall 2010, vii). The supposed inevitability of dominance by the eBook is redolent of the salesman's hype.

Will a 'digital edition' of, say, Leiden BPL 36 ever substantially improve on what the scholar experiences by face-to-parchment (skin-to-skin) or face-to-screen confrontation with the manuscript, or by learning to decipher the now standard edition of the glosses (O'Sullivan 2010; Figure 9 on the facing page)? In Radiant Textuality, Jerome McGann points out that "electronic texts have a special virtue that paper-based texts do not have: They can be designed for complex interac- 


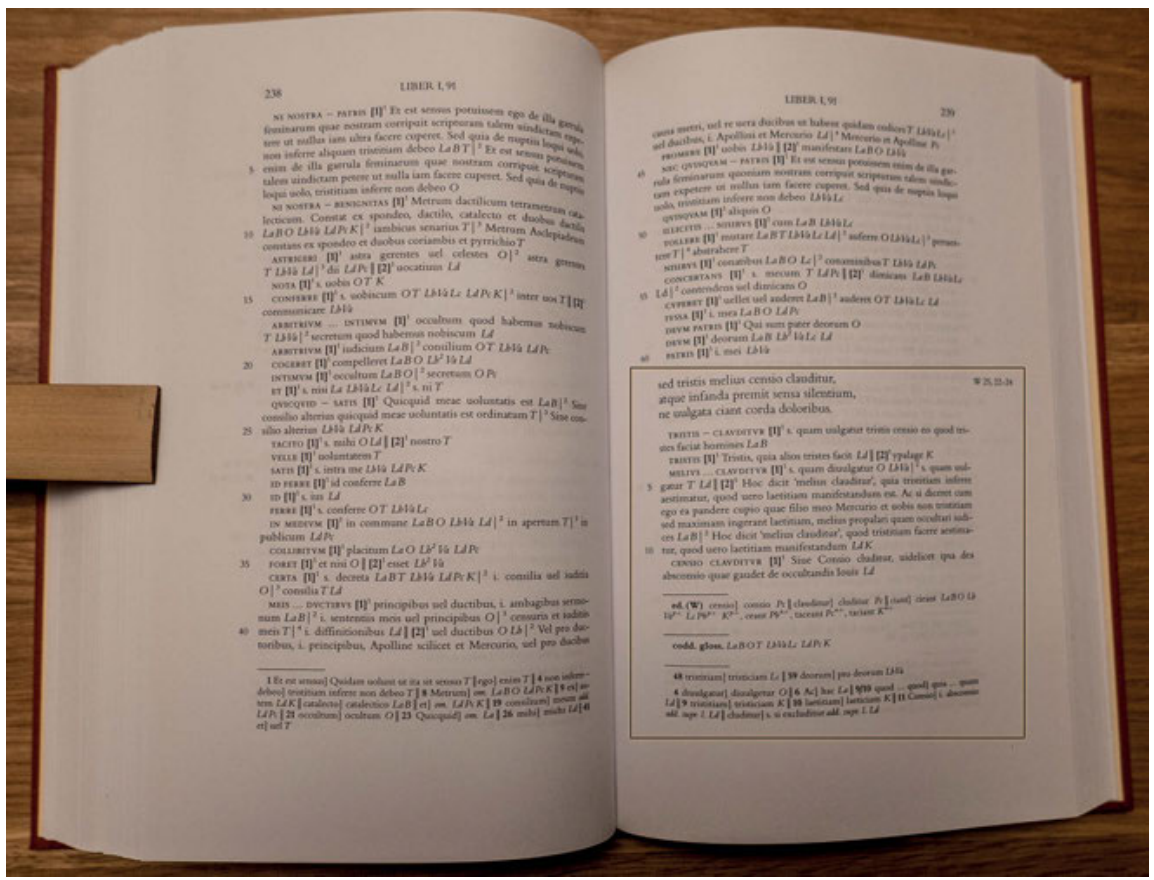

Fig. 9: The standard critical edition of De nuptiis, Books I-II (O'Sullivan 2010), showing the editor's treatment of the relevant passage

tive transformations." $(2001,81)$ These, presumably, have been taking place in the minds of readers, via the annotated page, for a very long time. Those that are algorithmically describable pose no problem, but how about those that are not - the construals of textual meaning that bring us again to the verge of the metaphysician's den?

Here I must stop. I leave you with three suggestions regarding implementation. The first is to pay critical attention to the sciences of mind and machine: the cognitive sciences, especially Psychology; the related cognitive-historical studies of experiment since Gooding (esp. Steinle's and Rheinberger's); and the anthropology of human-machine interaction (esp. Lucy Suchman's). ${ }^{26}$ The second is to turn from mimesis to alterity, i.e. from imitation of human intelligence by machines to exploration of other, differently constituted intelligences, so that we can see as clearly as possible in which direction to develop digital aids to annotation. My third, last and most adventurous suggestion is to follow Maxwell's lead, that is, to

26 Suchman 2007; for overview and background Duguid 2012. 
seek analogical help from uses of combinatorial enquiry wherever it is to be found: at home, in the natural sciences and Mathematics, and abroad, from other people, in other times, places and cultures. What have people done with counting and sorting when, unassisted, they were at a loss to proceed?

\section{Bibliography}

Anderson, Michael L. After Phrenology, Neural Reuse and the Interactive Brain. Cambridge, MA: MIT Press. 2014.

Baird, Jennifer A. and Claire Taylor (Eds.), Ancient Graffiti in Context. London: Routledge. 2010.

Bartlett, Frederic C. Remembering: A Study in Experimental and Social Psychology. Cambridge: Cambridge University Press. [1932] 1995.

Bate, Walter Jackson. Negative Capability: The Intuitive Approach in Keats. New York: Contra Mundum Press. [1939] 2012.

Berge, Claude. Principles of Combinatorics. Trans. From Principes Combinatoire. New York: Academic Press. [1968] 1971.

Bernard, Claude. An Introduction to the Study of Experimental Medicine. Trans. Henry Copley Greene. New York: Henry Schuman. [1865] 1949.

Bradley, John. Pliny: A model for digital support of scholarship. In: Journal of Digital Information 9.1. 2008. URL: https://journals.tdl.org/jodi/index.php/jodi/article/view/209/198 (13.01.2020).

Bradley, John. Towards a Richer Sense of Digital Annotation: Moving Beyond a "Media” Orientation of the Annotation of Digital Objects. In: Digital Humanities Quarterly 6.2. 2012. URL: http://www.digitalhumanities.org/dhq/vol/6/2/000121/000121.html (13.01.2020).

Brown, John Seely. Idea Amplifiers - New Kinds of Electronic Learning Environments. In: Educational Horizons 63.3. Bloomington: Phi Delta Kappa International. 1985, pp. 108-112.

Buchwald, Jed Z. The Creation of Scientific Effects: Heinrich Hertz and Electric Waves. Chicago: University of Chicago Press. 1994.

Clark, Andy. Supersizing the Mind: Embodiment, Action and Cognitive Extension. Oxford: Oxford University Press. 2008.

Clark, Andy et al. Whatever next? Predictive brains, situated agents, and the future of cognitive science. Target article with commentaries and a response. In: Behavioral and Brain Sciences 36.3. Cambridge: Cambridge University Press. 2013, pp. 181-253.

Crawford, Elspeth. Learning from Experience. In: Gooding and James (1985). London: Palgrave. 1985, pp. 211-227.

Danziger, Kurt. Marking the Mind: A History of Memory. Cambridge: Cambridge University Press. 2008.

Daston, Lorraine and Peter Galison. Objectivity. New York: Zone Books. 2007.

Deleuze, Gilles. Difference and Repetition. Trans. Paul Patton. London: Continuum. [1968] 1994.

DeRose, Steven J. Expanding the Notion of Links. In: Proceedings of ACM Hypertext 89 Conference November 5-8, 1989, Pittsburgh, Pennsylvania. New York: ACM Press. 1989, pp. 249-257. URL: https://www.interaction-design.org/literature/conference/proceedingsof-acm-hypertext-89-conference (13.01.2020). 
Derrida, Jacques. Of Grammatology. Corr. edn. Trans. Gayatri Chakravorty Spivak. Baltimore, MD: The Johns Hopkins University Press. [1967] 1997.

Derrida, Jacques. Structure, Sign and Play in the Discourse of the Human Sciences. In: Writing and Difference. Trans. Alan Bass. London: Routledge. [1966] 2001, pp. 278-294.

Dinkova-Bruun, Greti and Tristan Major (Eds.). Teaching and Learning in Medieval Europe: Essays in Honour of Gernot R. Wieland. Turnhout, Belgium: Brepols. 2017.

Donato, Eugenio. Structuralism: The Aftermath. SubStance 3.7. Baltimore, MD: The Johns Hopkins University Press. 1973, pp. 9-26.

Draaisma, Douwe. Metaphors of Memory: A history of ideas about the mind. Cambridge: Cambridge University Press. 2000.

Dronke, Peter. Fabula: Explorations into the Uses of Myth in Medieval Platonism. Leiden: E. J. Brill. 1974.

Dronke, Peter (Ed.). A History of Twelfth-Century Western Philosophy. Cambridge: Cambridge University Press. 1992.

Duguid, Paul. On rereading. Suchman and Situated Action. In: Le Libellio d’Aegis 8.2. Citeseer. 2012, pp. 3-9. URL: http://lelibellio.com/wp-content/uploads/2013/01/Libellio26.pdf (13.01.2020).

Eco, Umberto. The Open Work. Trans. Anna Cancogni. Cambridge MA: Harvard University Press. 1989.

Eco, Umberto. Opera Aperta. Milano: RCS Libri. [1962] 1997.

Engelbart, D. C. Augmenting Human Intellect: A Conceptual Framework. Stanford Research Institute Project No. 3578. Menlo Park, CA: Stanford Research Institute. 1962.

Etzelmüller, Gregor and Christian Tewes (Eds.). Embodiment in Evolution and Culture. Tübingen: Mohr Siebeck. 2016.

Faraday, Michael. Faraday's Diary: Being the Various Philosophical Notes of Experimental Investigation. Ed. Thomas Martin. 4 volumes. London: G. Bell and Sons. 1932-1933. DOI: $10.1038 / 133627 \mathrm{a} 0$.

Flusser, Vilém. Nachgeschichte: Eine korrigierte Geschichtsschreibung. Stefan Bollmann and Edith Flusser (Eds.). Frankfurt am Main: Fischer Taschenbuch Verlag. 1997.

Flusser, Vilém. The Gesture of Writing. In: Nancy Ann Roth (trans.), Gestures. Minneapolis, MN: University of Minnesota Press. [1991] 2014, pp. 19-25.

Frazer, Ray. The Origin of the Term “Image”. In: ELH 27.2. Baltimore, MD: The Johns Hopkins University Press. 1960, pp. 149-161. DOI: 10.2307/2871916.

Gardner, Martin. Logic Machines and Diagrams. New York: McGraw-Hill. 1958.

Gibson, James J. The Theory of Affordances. In: The Ecological Approach to Visual Perception. Boston: Houghton Mifflin. [1979] 1986, pp. 127-137.

Gooding, David. “In Nature's School”: Faraday as an Experimentalist. In: David Gooding and Frank A. J. L. James (Eds.), Faraday Rediscovered). Basingstoke, Houndmills: The Macmillan Press Ltd. 1985, pp. 105-135.

Gooding, David. How Do Scientists Reach Agreement about Novel Observations? In: Studies in the History and Philosophy of Science 17.2. Amsterdam: Elsevier. 1986, pp. 205-230. DOI: 10.1016/0039-3681(86)90026-9.

Gooding, David. Experiment and the Making of Meaning: Human Agency in Scientific Observation and Experiment. Dordrecht: Kluwer. 1990.

Gooding, David. Putting Agency Back into Experiment. In: Andrew Pickering (Ed.), Science as Practice and Culture. Chicago: University of Chicago Press. 1992, pp. 65-112. 
Gooding, David. Varying the Cognitive Span: Experimentation, Visualisation, and Computation. In: Hans Radder (Ed.), The Philosophy of Scientific Experimentation. Pittsburgh, PA: Pittsburgh University Press. 2003, pp. 255-301.

Gooding, David and Frank A. J. L. James (Eds.). Faraday Rediscovered: Essays on the Life and Work of Michael Faraday, 1791-1867. London: Macmillan Press. 1985.

Hacking, lan. Representing and Intervening: Introductory Topics in the Philosophy of Natural Science. Cambridge: Cambridge University Press. 1983.

Halasz, Frank G., Kate Dobroth, Richard Furuta, Catherine C. Marshall, and Elli Mylonas. Reflections on NoteCards: Seven Issues for the Next Generation of Hypermedia Systems [followed by 4 commentaries and a reply]. In: ACM Journal of Computer Documentation 25.3. New York, NY: ACM Press. 2001, pp. 71-114. DOI: 10.1145/507317.507321.

Halasz, Frank G., Thomas P. Moran, and Randall H. Trigg. NoteCards in a Nutshell. CHI '87 Proceedings of the SIGCHI/GI Conference on Human Factors in Computing Systems and Graphics Interface. Toronto, Ontario, Canada - April 05 - 09, 1987. New York, NY: ACM Press. 1987, pp. 45-52.

Holmes, Frederic Lawrence. Lavoisier and the Chemistry of Life: An Exploration of Scientific Creativity. Milwaukee, WI: University of Wisconsin Press. 1985.

Holmes, Frederic Lawrence. Investigative Pathways: Patterns and Stages in the Careers of Experimental Scientists. New Haven, CT: Yale University Press. 2004.

Hunter, Jane. Collaborative Semantic Tagging and Annotation Systems. In: Annual Review of Information Science and Technology 43.1. Hoboken, NJ: Wiley. 2009, pp.1-84. DOI: 10.1002/aris.2009.1440430111.

Hutchins, Edwin. Cognition in the Wild. Cambridge, MA: MIT Press. 1995.

Hutchins, Edwin. Cognitive Ecology. In: Topics in Cognitive Science 2.4. Hoboken, NJ: Wiley. 2010, pp. 705-715. DOI: 10.1111/j.1756-8765.2010.01089.x.

Inwood, Brad and Willard McCarty (Eds.). History and Human Nature: An Essay by G. E. R. Lloyd with Invited Responses. In: Interdisciplinary Science Reviews 35.3-4. London: Taylor \& Francis. 2010, pp.199-200. DOI: 10.1179/030801810X12786672846327.

Ippolito, Maria F. and Ryan D. Tweney. The Inception of Insight. In: Robert J. Sternberg and Janet E. Davidson (Eds.), The Nature of Insight. Cambridge, MA: MIT Press. 1995, pp. 433-462.

Jackson, Heather J. Marginalia: Readers Writing in Books. New Haven, CT: Yale University Press. 2001.

Jackson, Heather J. Romantic Readers: The Evidence of Marginalia. New Haven, CT: Yale University Press. 2005.

Jacob, François. The Statue Within: An Autobiography. Trans. Franklin Philip. Cold Spring Harbor, NY: Cold Spring Harbor Laboratory Press. [1987] 1988.

Keats, John. Selected Letters of John Keats. Rev. edn. Ed. Grant F. Scott. Cambridge, MA: Harvard University Press. 2002.

Keller, Evelyn Fox. The Dilemma of Scientific Subjectivity in a Postvital Culture. In: Peter Galison and David J. Stump (Eds.), The Disunity of Science: Boundaries, Contexts, and Power. Stanford, CA: Stanford University Press. 1996, pp. 417-427.

Keller, Evelyn Fox. Organisms, Machines, and Thunderstorms: A History of Self-Organization, Part One. In: Historical Studies in the Natural Sciences 38.1. Berkeley, CA: University of California Press. 2008, pp. 45-75.

Krajewski, Markus. Paper Machines: About Cards \& Catalogs, 1548-1929. Peter Krapp (trans.). Cambridge, MA: MIT Press. 2011. 
Kuhn, Thomas S. The Structure of Scientific Revolutions. 4th (50th Anniversary Edition). Chicago: University of Chicago Press. [1962] 2012.

Lewisohn, Cedar. Street Art: The Graffiti Revolution. London: Tate Publishing. 2008.

Lloyd, Geoffrey E. R. The Invention of Nature. In: Methods and Problems in Greek Science. Cambridge: Cambridge University Press. 1991, pp. 417-434.

Lloyd, Geoffrey E. R. Being, Humanity, and Understanding: Studies in Ancient and Modern Societies. Oxford: Oxford University Press. 2012.

Lloyd, Geoffrey E. R. Cosmology without Nature. In: The Ambivalences of Rationality: Ancient and Modern Cross-Cultural Explorations. Cambridge: Cambridge University Press. 2018, pp. 22-38.

Luhmann, Niklas. Archimedes und wir. Berlin: Merve Verlag. 1987.

Mailer, Norman. The Faith of Graffiti. In: Esquire: The Magazine for Men. Chicago, IL: Arnold Gingrich. May 1974, pp.77-88, 154-158. URL: https://classic.esquire.com/article/1974/5/ 1/the-faith-of-graffiti (13.01.2020).

Marshall, Catherine C. Reading and Writing the Electronic Book. Williston, VT: Morgan \& Claypool. 2010.

Maturana Romesin, Humberto. Autopoiesis, Structural Coupling and Cognition: A History of These and Other Notions in the Biology of Cognition. In: Cybernetics \& Human Knowing 9.3-4. Exeter: Imprint Academic. 2002, pp. 5-34. URL: https://www.ingentaconnect.com/content/ $\mathrm{imp} / \mathrm{chk} / 2002 / 00000009 /$ F0020003/121 (13.01.2020).

Maxwell, James Clerk. On Faraday's Lines of Force. In: Transactions of the Cambridge Philosophical Society 10.1. Cambridge: Cambridge University Press. 1864, pp. 27-83.

Maxwell, James Clerk. Address to the Mathematical and Physical Sections of the British Association. In: William Davidson Niven (Ed.), The Scientific Papers of James Clerk Maxwell. New York: Dover. Cambridge: Cambridge University Press. [1870] 1890, pp. 215-229.

Mayr-Harting, Henry. Church and Cosmos in Early Ottonian Germany: The View from Cologne. Oxford: Oxford University Press. 2008.

Mayr-Harting, Henry. Augustine of Hippo, Chelles, and the Carolingian Renaissance: Cologne Cathedral Manuscript 63. Frühmittelalterliche Studien, Sonderdruck, Band 45. Berlin: Walter de Gruyter. 2011, pp. 51-76.

McGann, Jerome. Radiant Textuality: Literature after the World Wide Web. New York: Palgrave. 2001.

McLeish, Tom. The Poetry and Music of Science: Comparing Creativity in Science and Art. Oxford: Oxford University Press. 2019.

Murray, James A. H. Thirteenth Address of the President, to the Philological Society, Delivered at the Anniversary Meeting, Friday, 16th May, 1884. In: Transactions of the Philological Society 19.1. Hoboken, NJ: Wiley. 1884, pp. 501-527. DOI: 10.1111/j.1467-968X.1884.tb00096.x.

Neef, Sonja. Killing Kool: The Graffiti Museum. In: Art History 30.3. Hoboken, NJ: Wiley. 2007, pp. 418-431. DOI: 10.1111/j.1467-8365.2007.00553.x.

Nersessian, Nancy J. Maxwell and the Method of "Physical Analogy": Model-Based Reasoning, Generic Abstraction, and Conceptual Change. In: David B. Malament (Ed.), Reading Natural Philosophy: Essays in the History and Philosophy of Science and Mathematics. Chicago, IL: Open Court. 2002, pp.129-166.

Nersessian, Nancy J. Creating Scientific Concepts. Cambridge, MA: MIT Press. 2008.

Neumann, Martin and Stephen J. Cowley. Human Agency and Resources of Reason. In: Stephen J. Cowley and Frédéric Valée-Tourangeau (Eds.), Cognition Beyond the Brain: Computation, 
Interactivity and Human Artifice. 2nd edn. Cham, Switzerland: Springer Interactional Publishing AG. 2017, pp. 175-192.

Norman, Donald A. and Stephen W. Draper (Eds.). User Centered System Design: New Perspectives on Human-Computer Interaction. Hillsdale, NJ: Lawrence Erlbaum. 1986.

Nyce, James M. and Paul Kahn. From Memex to Hypertext: Vannevar Bush and the Mind's Machine. Boston: Harcourt Brace Jovanovich. 1991.

O’Sullivan, Sinéad (Ed.). Glossae Aevi Carolini in libros I-II Martiani Capellae De nuptiis Philologiae et Mercurii. Turnhout: Brepols Publishers. 2010.

O'Sullivan, Sinéad. The Sacred and the Obscure: Greek and the Carolingian Reception of Martianus Capella. In: Journal of Medieval Latin 22. Turnhout: Brepols Publishers. 2012, pp. 67-94. DOI: 10.1484/J.JML.1.10252.

0’Sullivan, Sinéad. Reading and the Lemma in Early Medieval Textual Culture. In: Mariken Teeuwen and Irene van Renswoude (Eds.), The Annotated Book in the Early Middle Ages: Practices of Reading and Writing. Turnhout: Brepols Publishers. 2017, pp. 371-396. DOI: 10.1484/M.USML-EB.5.115028.

O’Sullivan, Sinéad. Glossing Vergil and Pagan Learning in the Carolingian Age. In: Speculum 93.1. Chicago, IL: University of Chicago Press. 2018, pp. 132-165.

$\mathrm{Ou}$, Li. Keats and Negative Capability. London: Continuum. 2009.

Pickering, Andrew. The Cybernetic Brain: Sketches of Another Future. Chicago, IL: University of Chicago Press. 2010.

Ragazzoli, Chloé, Ömür Harmanşah, Chiara Salvador, and Elizabeth Frood (Eds.). Scribbling Through History: Graffiti, Places and People from Antiquity to Modernity. London: Bloomsnbury Academic. 2018.

Reynolds, Leighton Durham and Nigel Guy Wilson. Scribes and Scholars: A Guide to the Transmission of Greek and Latin Literature. 3rd edn. Oxford: Clarendon Press. 1991.

Rheinberger, Hans-Jörg. An Epistemology of the Concrete: Twentieth-Century Histories of Life. G. M. Goshgarian (trans.). Durham, NC: Duke University Press. [2006] 2010.

Rochberg, Francesca. Before Nature: Cuneiform Knowledge and the History of Science. Chicago: University of Chicago Press. 2016.

Rogers, Janine. Graffiti and the Medieval Margin. In: Chloé Ragazzoli, Ömür Harmanşah, Chiara Salvador and Elizabeth Frood (Eds.), Scribbling through History: Graffiti, Places and People from Antiquity to Modernity. London, New York: Bloomsbury. 2018, pp. 175-188. DOI: 10.5040/9781474288842.ch-011.

Scarry, Elaine. The Made-Up and the Made-Real. In: Yale Journal of Criticism 5.2. New Haven, CT: Yale University Press. 1992, pp. 239-249.

Sprat, Tho[mas]. The History of the Royal Society of London for the Improving of Natural Knowledge. London: J. Martyn. 1667.

Steinle, Friedrich. Exploratory Experiments: Ampère, Faraday, and the Origins of Electrodynamics. Alex Levine (trans.). Pittsburgh, PA: University of Pittsburgh Press. [2005] 2016.

Suchman, Lucy A. Human-Machine Reconfigurations: Plans and Situated Actions, 2nd Edition. Cambridge: Cambridge University Press. 2007.

Taton, René. Reason and Chance in Scientific Discovery. Arnold J. Pomerans (trans.). London: Hutchinson Scientific and Technical. 1957.

Taylor, Charles. The Language Animal: The Full Shape of the Human Linguistic Capacity. Cambridge, MA: Harvard University Press. 2016.

Teeuwen, Mariken and Irene van Renswoude (Eds.). The Annotated Book in the Early Middle Ages: Practices of Reading and Writing. Turnhout, Belgium: Brepols Publishers. 2017. 
Tversky, Barbara. Some Ways of Thinking. In: Lorenzo Magnani (Ed.), Model-Based Reasoning in Science and Technology: Theoretical and Cognitive Issues. Heidelberg: Springer. 2014, pp. 3-8.

Tweney, Ryan D. Cognitive-Historical Approaches to the Understanding of Science. In: Gregory J. Feist and Michael E. Gorman (Eds.), Handbook of the Psychology of Science. New York: Springer Publishing. 2013, pp. 71-93.

von Neumann, John. First Draft of a Report on the EDVAC. In: IEEE Annals of the History of Computing 15.4. Piscataway, NJ: IEEE. [1945] 1993, pp. 27-75. DOI: 10.1109/85.238389.

Wieland, Gernot R. The Latin Glosses on Arator and Prudentius in Cambridge, University Library, Ms. Gg.5.35. Turnhout: Brepols Publishers. 1983.

Wieland, Gernot R., Carin Ruff, and Ross G. Arthur (Eds.). Insignis Sophiae Arcator: Essays in Honour of Michael W. Herren on his 65th Birthday. Turnhout: Brepols Publishers. 2006.

Williams, Raymond. Keywords: A Vocabulary of Culture and Society. Rev. edn. New York: Oxford University Press. [1976] 1983. 
